\title{
HANKISS ELEMÉR RÁDIÓS MUNKÁSSÁGÁRÓL
}

\section{ON ELEMÉR HANKISS'S WORK AT THE HUNGARIAN RADIO CORPORATION}

\author{
Kondor Katalin \\ a Magyar Rádió korábbi elnöke, a kőszegi Felsőbbfokú Tanulmányok Intézete ösztöndíjasa \\ info@iask.hu
}

\begin{abstract}
ÖSSZEFOGLALÁS
Hankiss életének csak egy kis szeletét töltötte ki a rádiós munka, ám e téren is maradandót hozott létre. Szép számmal vannak olyan műsorok, melyek kiváló alapot szolgáltatnak a megismerésére és ötletei továbbgondolására. A hatvanas években készült irodalmi összeállítások és viták, szociológiai műsorok szinte hiánytalanul megvannak. Az 1996-ban indult Fórum sorozatban olyan dolgokról beszélgetnek, melyekről nem szoktunk. „Tudományos" szinten is végigvihetnénk a gondolatot: vajon otthon vagyunk-e a világban? Mit tettünk történelmünk során azért, hogy valamelyest otthon érezzük magunkat? Ez a műsorsorozat is alkalmas arra, hogy valamely egyetemi képzés újratárgyalja a benne felvetett kérdéseket. Ám mindenképpen jó lenne, ha Hankiss gondolatait az egyetemek falain kívül is megismerhetnék.
\end{abstract}

\section{ABSTRACT}

The present study is based on research conducted at the archive of the Hungarian Radio Corporation. Even though working at the national radio covered only a small segment of Elemér Hankiss's career, he left a lasting imprint on this field as well. His work at the Radio even represents a period of his oeuvre. The radio programmes of Hankiss cover the fields of literature, sociology and politics. The study presents a few highly successful programmes of Hankiss by also reflecting on the possible importance of them for today's radio listeners and thinkers if they were to be rediscovered.

Kulcsszavak: Hankiss, rádió, Magyar Rádió, politika, rendszerváltás

Keywords: Hankiss, radio, the Hungarian Radio Corporation, politics, democratic transformation

Sokszor hallottuk már, hogy ebben az információ-cunami által sújtott világban nincsenek polihisztorok. Nincsenek, mert ilyen tömegü ismeretet, amennyi naponta keletkezik, egy ember képtelen befogadni és rendszerezni, valamint beilleszteni mindennapi életébe, tudástárába. A lexikonok úgy határozzák meg e 
fogalmat, hogy a polihisztor olyan tudósember, aki többféle tudományághoz is ért, és kiemelkedőt is alkot. A meghatározás mellé azt is hozzáteszik, hogy polihisztorok föleg az ókorban, az iszlám aranykorában és a reneszánsz idején éltek és alkottak, mivel e korokban kaptak rendkívüli figyelmet a különböző tudományok és a természet megismerésére való törekvés. Mára viszont a tudományok oly szerteágazó, összetett ismeretanyaggal bővültek, amelyeket a hatékonyabb kutathatóságért résztudományokra kellett bontani, és ezen résztudományokra specializálódott szakemberekkel vizsgáltatni. S bár vannak, akik azt állítják, bármelyikünk előtt nyitva áll a lehetőség, hogy polihisztor legyen, én ebben nem hiszek. S nem is láttam arra példát, hogy valaki elhatározta volna, én bizony polihisztor leszek, $\mathrm{s}$ az is lett. Hiába határozom én el, hogy fizikus leszek, nem fog menni, kivált úgy nem, ha a polihisztor létbe vitathatatlanul beletartozónak vesszük, hogy az illető kiemelkedőt és maradandót alkosson. A művelt ember megvalósítható célja „csak” az lehet, hogy folyamatosan új dolgokat tanulva, kíváncsian élje életét.

Hankiss Elemér valószínúleg sosem tüzte ki célul maga elé, hogy polihisztorrá váljon, én mégis azt gondolom, hogy egy furcsa csavarral sikerült neki. Ez a furcsa csavar nem más, mint hogy ő az embert akarta felemelni, erkölcsileg magasabb szintre léptetni az összes, általa mélyen ismert tudományág segítségével. Ezek a tudományágak: irodalom, a művészet szinte valamennyi ága, a szociológia, pszichológia, politológia. Tehát az ember erkölcsi felemelkedésének segítésében volt polihisztor.

Nemrégiben Hankiss Elemér rádiós munkásságának összegyüjtésére kaptam megbízást a Felsőbbfokú Tanulmányok Intézetétől. Mint tudjuk, Hankiss életének csak egy kis szeletét töltötte ki a rádiós munka, ám e téren is maradandót hozott létre. Sajnos a Magyar Rádióban több olyan müsort is letöröltek, amelyben Hankiss Elemér szerepelt. Szép számmal vannak azonban meglévő müsorok, melyek kiváló alapot szolgáltatnak az ő megismerésére és ötletei továbbgondolására. Azok az irodalmi összeállítások, melyek a hatvanas években keletkeztek, szinte hiánytalanul megvannak. Ezek a músorok nagyon igényesek. Ő pontosan érzékelte, hogy az erkölcsi prédikációknál és a szájbarágós oktatásnál sokkal hatékonyabb, ha az irodalom erejével próbálja megfogni a hallgatót. Az irodalmi adaptációkban és az általa összeállított zenés-verses müsorokban remek színészek szerepelnek, $\mathrm{s}$ azt csak mellékesen jegyzem meg, hogy mivel az írásos anyag is rendelkezésre áll - a hangfelvétel mellett -, ezeket az összeállításokat mai színészekkel is újra fel lehet venni. Vagy különleges, rá emlékező összejöveteleken közönség előtt lejátszani például a Hipp-hopp farsang! címü összeállítást, melyben a 15-16. századtól napjainkig eleveníti fel a farsangi szokásokat. Szinte az összes müsora kapcsán lehetne arról is beszélgetni, milyen ereje van a hangnak, a szónak. Csakhogy ebben, a mindent leginkább erőszakos képi fantáziával ábrázoló világban nem bíznak az egyén képi fantáziájában, holott azt már sokan bebizonyították, hogy a hang, például egy rádiójáték, sokkal inkább megmozgatja 
a hallgató fantáziáját, mintha mindent „készen” kap, „megképesítve”. Ezt tudta Hankiss is, azért szerkesztett ennyi igényes irodalmi összeállítást (no, meg könyvet is írt a szó erejéről). Azok a müsorok pedig, melyek kimondottan diákoknak készültek, ma is alkalmasak esztétikai képzésre, akár meghirdetett kurzusok formájában is. Az általa jegyzett, irodalomról, esztétikáról szóló vitamüsorok, vagy amelyekben riportalanyként, meghívottként szerepelt, szintén olyanok, amelyeket be lehetne vonni akár a felsőfokú képzésbe is. Bemutatható általuk, hogyan „vándorol” egy-egy téma több évszázadon át a zenében, irodalomban (például a Don Juan-jelenség, melyről ugyancsak készített müsort). Vagy hogyan változott az irodalom és a közönség viszonya a hatvanas évek óta? Hogyan lehet olvasó-zseni az ember? Megszüntethetö-e a szakadék írók és olvasók között? Mit gondoljunk a giccsről, a slágerről, a ponyváról? Szóval ezek a vitamüsorok mind-mind remek alapot adnak müveltségünk csiszolására, vitaképességünk fejlesztésére, az álmüvészet felismerésére, múltbéli és jelen idejű irodalmi életünk megértésére, és sok tanulsággal szolgálnak. Időről időre ma is meg kellene szervezni ezeket a találkozókat nagy nyilvánosság előtt, tehát rádióban, tévében. A hatvanas években, amikor Hankiss müsorokat készített ezekről a témákról, már sok statisztikai adat került a nyilvánosság elé az irodalomszociológiai felmérésekből. Kik olvasnak, s mit falun, városban, milyenek a példányszámok. Ez volt az az időszak, amikor Aranytól Jókaiig, Gárdonyitól Mikszáthig, Mórától, Petőfitől Móriczig milliós példányszámban jelentek meg a müvek. És a külföldi klasszikusok is hasonló példányszámot „produkáltak”. Hankiss egyebek közt arról elmélkedik, vajon hogyan lehet az olvasót bekapcsolni a küzdelembe az íróval és a müvel. Az irodalom - mondja - mindig dialógus, mert az olvasó válaszol az írónak, ha nem is hangos szóval, hanem csak önmagában. Az olvasásnak szerinte éppúgy megvannak a maga zsenijei, mint az írásnak. Kiderül, a selejtesebb, kisebb igényủ múvek iránt már akkor is többen érdeklödtek. Nos, úgy gondolom, statisztikai adatok ma is vannak ezekről a jelenségekröl. Az akkori tapasztalatoknak a maiakkal való öszszehasonlítása minden bizonnyal érdekes, hasznos és tanulságos lenne.

Amint már említettem, Hankiss mindent erkölcsi szemszögből közelített meg, a tettek erkölcsi okát kutatta. Jó példa erre az Amerika országútjain címü müsora. Ebben az 1916-ban öngyilkosságba menekülő Jack Londonról van szó, aki gazdag, sikeres és boldog ember volt, legalábbis a környezete szerint. Hankiss azt vizsgálja, milyen küzdelmek, vívódások vezettek a tragikus eseményhez, $\mathrm{s}$ próbálja megérteni a bukás okát. Irodalmi, pszichológiai és társadalomtudományi tudnivalók „ragadnak” a hallgatóra szinte észrevétlenül, mondhatnám, szellemes ötleteivel mindig több legyet üt egy csapásra. Különösek a költők verseiből készített összeállításai is. Egy példa arra, hogy ezekbe szintén „,belevitt egy csavart”. Érzelmes párbeszéd címü müsorában két ember kapcsolatának majdnem minden változatáról, árnyalatáról képes sokat mondani a versek segítségével. Ebben a müsorban Horatius, egy régi francia népdal, egy francia népballada, Burns, Ver- 
laine és Victor Hugo írásaiból áll össze a színészek által előadott produkció. Nos, ha rajtam múlna, ajánlanám is kísérletképpen gimnáziumoknak, egyetemeknek meghallgatásra, s ez egyben tanításnak is számítana. S ha most az olvasó elgondolkodik, hall-e ilyen típusú müveltséget emelö, erkölcsi példát adó müsorokat a rádióban, nem lehet más a válasza, mint a NEM. Mert nem hall.

Tanulságos irodalmi vitamúsorait is megemlíteni, s meghallgatni. Lényéből fakadóan szelíd szavú, vitákban türelmes és igazságkereső ember, akitől nemigen tapasztalhatunk lekicsinylö, másokat elnyomni akaró magatartást. A hatvanas évek végén készítette el kétrészes - ma is aktuális témájú - vitamüsorát Giccs, sláger, ponyva címmel. Arról beszélgetnek, fölfoghatjuk-e a művészetet úgy, mint ami kikapcsolódást jelent csupán, az élet nehézségeiből való kikapcsolódást. És vajon az úgynevezett komoly, igényes müvészet, irodalom, nem zárkózik-e be napjainkban olyan forma- és gondolatvilágba, amely nehezen érthetö, s ezért kevesek számára hozzáférhető. A vitában Hankiss annak a véleményének ad hangot, hogy a giccs sablonokkal dolgozik. Nem minden sláger giccs természetesen, egy szöveget az tesz giccsessé, ha túlhalmozza a szép mondatokat, sablonokat. Egyfajta etikai inflációval próbál hatást kelteni. Mindig jellemzője a nagyzolás, az, hogy túl szép akar lenni, szebb bárki és bármi másnál. Az ötvenes évek sematizmusát is szóba hozza, és arról is beszélgetnek a müsorban, hogy a ponyva leszoktatja-e az igazi irodalomról az olvasót. A giccs meg a ponyva, valamint a sláger térhódítása nem kis mértékben müveltségi tényezők függvénye. A kevésbé müvelt olvasóra jobban hat a giccs. Ha akarunk ellene küzdeni, akkor az általános műveltségi színvonalat kell folyton emelni. Hogy olyan olvasó, olyan müélvező szülessen, akit már nem kell meggyőzni arról, hogy ne olvasson giccset, hanem azt eleve üresnek, sablonosnak érezze. Mondanunk sem kell, milyen fontos téma ez ma, amikor például női folyóiratok, hetilapok tele vannak elképesztően giccses álirodalommal. Ehhez kapcsolódva idézem Hankiss egyik mondatát a vitából: „Ma, amikor a társadalmi rétegek nap mint nap kiszakadnak régi, hagyományos körükből, a faluból, a kisvárosból, elvesztik biztos stiláris érzéküket. Minden nap más hatás alatt vannak, és igen bizonytalan állapotban, erősebben ki vannak téve az úgynevezett társadalmi stílushatásoknak. Ez a hatás pedig elsősorban tulajdonképpen mindig a divatos, a mủvelteknek számító, vagy jómódúaknak számító rétegektől lefele van. Az a divatos, amit a legmenőbb színésznő visel, az a könyv divatos, amit az én legmüveltebb barátom olvas és ismer. Tehát amennyiben nincs meg már a saját biztos, szilárd ítéletem, nagyon könnyen hatása alá kerülök ilyen »felülről jövő« hatásoknak. Ellenszer: biztos értékrenden alapuló stílust és kultúr-érzéket kifejleszteni."

Elhagyva az irodalom világát, nézzük, ami már túlmutat a Hankiss által szerkesztett irodalmi összeállításokon, következzenek azok a szociológiai müsorok, melyekben maga is gyakran közremüködött. Ezek ugyancsak kiváló alapot adhatnak felsőfokú tanulmányokat végző diákok oktatásához. Szinte tálcán kínál- 
ja, milyen úton kellene haladni műveltségünk gyarapításához. El tudok képzelni például egy kurzust, amely fontos szociológiai fogalmakat tárgyal, s azok időbeni fejlődését is vizsgálja. Mi változott például a hetvenes évek óta értékeinket és normáinkat illetően? Másképp mérik-e ma a teljesítményt, mint régebben? Milyen a tanár-diák viszony ma, a régihez képest? Egyáltalán, mi az, hogy érték? Felülírhatja-e az érdek az értéket? Hogyan lehet egy társadalomnak hiteles értékrendje? Mindezen témákról rendszeresen készített müsort Hankiss. Millió ötletet dobnak fel ezek a müsorok, amelyek ma ugyancsak sajnálatosan hiányoznak az elektronikus média müsoraiból, de a többi médium sem igen, vagy legalábbis nem elegendő időben és hatékonysággal foglalkozik erkölcstannal, értékekkel, vitakultúrával, viselkedéskultúrával. Ám még ezeknél is érdekesebb és hasznosabb az a müsorsorozat, melyben erkölcsi értékrendjük meghatározására „kényszeríti” a résztvevőket, egy-egy történet meghallgatása után. A történeteket nyugodtan „el lehet lopni” Hankisstól, de természetesen, ami fontos, hogy értékes vita kerekedjen egy-egy téma kapcsán. (A Disputa címü vitamüsorra utalok, valamint az Erkölcsi csapdák címü sorozatra.) Szóval bármely kutatóintézet millió formában felhasználhatja és továbbgondolhatja az ő hagyatékát. Megéri!

Tudományos kutatás alapját is képezhetné Hankiss erkölcsi kérdéseket feszegető müsorsorozata. Az életünk ugyanis hihetetlen gyorsasággal változott az elmúlt három évtizedben. Ha valaki ezeket a müsorokat végigelemzi, majd a történeteket mai közreműködők előtt lejátssza, és reagálásra készteti a műsor vendégeit, kiválóan elemezhető, merre és hogyan mozdult erkölcsi életünk három évtized alatt. Biztos vagyok benne, hogy érdekes következtetésekre lehetne jutni a két időszak összehasonlításával. Két példát idézek, hogy érzékeltessem, milyen módszert talált ki erkölcsi kérdések megvitatására Hankiss. Az Erkölcsi csapdák müsorsorozat egyik darabja a véletlen szerepéről elmélkedik. A szerkesztő ebben a sorozatban mindig egy saját maga által megírt és színészekkel eljátszatott történetet mutat be, a társadalom különböző rétegeiből jött társaság előtt. Ezúttal egy tragikus végü autóbaleset előzményeiröl szól a színjáték. Halálos balesetet szenved egy nagyon fiatal, fontos pozícióban lévő ember, akinek felesége, gyereke van. Mérnök az illető, és éppen a kocsiját viszi szervizbe, ahol korábban nem igazán gondosan jártak el. Aznap a feleségével is veszekedett. Olyan balszerencséje is van, hogy az úton, mely felé tart, még jelentős mennyiségü olaj is kiömlik, váratlan helyzet elé állítva öt. A történet elhangzása után megkérdezik a meghívott civil vendégeket, szerintük ki a felelős a mérnök haláláért? És miért éppen ő? Majd közösen beszélgetnek a történet erkölcsi tanulságairól. A szeretet, a tolerancia hiánya okozhatta a végzetet a riportalanyok szerint, no meg a feleséggel történt veszekedés. Mások az útviszonyokat is hibáztatják, megint mások pedig az autószerelőt, aki nem nézte át rendesen az autót, mert felületes volt. Többen az állandó rohanást, melyben élünk, nevezik meg a tragédia egyik okozójának. Kiderül, legtöbben a környezetet tesszük felelőssé a hasonló ügyekben. A társadalmi környezetet is. Senki sem 
felelős tehát, és mindenki. Rendkívül szerteágazó véleményeket hallunk a széles körből merített meghívottaktól. Van-e tehát véletlen? Hankiss a végén összegez: hiányzik az erkölcsi ideál az emberek életében. Nem kaptak ilyet. Az óvodában sem, mondja az egyik beszélgetőtárs, aki szerint az oviban úgy káromkodnak a gyerekek, mint egy kocsis. Megegyeznek abban, hogy az erkölcsi kérdések megítélése bonyolult feladat.

A másik müsorban a vita alapjául szolgáló példázat arról szól, hogy súlyos árvíz pusztít a vidéken. A víz közeledik, egy család bezáródott a házukba. Csónak nincs, amivel menekülhetnének. A nő apjának, a nagypapának két csónakja is van, de ő már három éve nem áll szóba a vejével. Némi családi vita után a férj mégis átmegy az apóshoz, ám az nem adja oda a nagy csónakot, mert amikor a nagymama halálos beteg volt, nem segített a vő. A férj ezek után ellopja a nagy csónakot, otthagyja a kisebbet, mert az lyukas. S pár óra múlva kiderül, a roszszabbik csónakban menekülő nagypapát elvitte az ár, és meghalt. A beszélgetésre ismét több embert hívtak. Első megtárgyalandó kérdés: joga volt-e elvinni a fiatal férjnek a csónakot? Igennel vagy nemmel kell válaszolni. Többen mondják, hogy joga volt. Nem tudták megtalálni a kompromisszumot. Kitérnek arra is, a vészhelyzet milyen viselkedést kíván. Ilyenkor muszáj mérlegelni, és gyorsan cselekedni. Érdekes okfejtések hangoznak el mindkét oldalról. Hankiss arra figyelmeztet, nagyon veszélyes útra lép az a társadalom, amely azt mondja, hogy rangsorolni kell az életek között társadalmi hasznosság szerint - miközben folyton rangsorolunk. Minden élet egyformán értékes. Ez volt Európa erkölcsi alapja évszázadokon át. Ám napjainkra már felerősödött a hasznosság mint egyetlen mérce, és messze lesüllyedt az emberi értéknek mint abszolút értéknek a sérthetetlensége, és az jött föl, hogy meg lehet ölni az embert, tízet, százat, milliókat is egy vélt társadalmi érdek vagy egy önző kisebbségi érdek védelmében. Ám ez az európai kultúra vége. Szerinte mindenkinek, az élet minden pillanatában képviselnie kell azt, hogy az emberi élet abszolút és sérthetetlen. Másfelől a társadalom szempontjából igenis vannak hasznosabb életek. Az ellentmondás feloldhatatlan, mindennap meg kell küzdenünk vele, akkor tudunk közeledni valamiféle erkölcsös magatartáshoz.

Számos műsorát lehetne még példaként felhozni és követendő mintaként elemezni. Mindegyikből az erkölcsi és jogi rend óhajtása érződik, s e két fogalomról, tehát egy társadalom erkölcséről és igazságos rendjéről magam is azt gondolom, hogy e kettő mindennek az alapja. Ugorjunk most a rendszerváltásnak nevezett folyamat kezdetéhez közeli időszakig. Csak röviden említem meg, hogy a gazdaság erkölcsével, az országban a nyolcvanas években uralkodó munkamorállal is foglalkozik müsor, melyben Hankiss elmondja véleményét, például Békesi László pénzügyminiszter-helyettessel vitatkozva. Érdekes és tanulságos lenne felmérni, ma mennyiben változott a helyzet az akkorihoz képest, pontosabban időről időre fel kellene mérni a gazdasági és munkamorál változását. Egy ilyen műsor még 
az uralkodó politikai eszmék mulandóságáról is kiváló vitaalapot szolgáltathat. Beleértve a „hol sikkad el a felelősség” kérdését is.

És elérkezünk a nyolcvanas évek végéhez, amikor 1988-89-ben már a rendszerváltás előkészítése folyt Magyarországon. Hankiss a szabadság arcairól, a társadalom átalakulásáról, az új elit kialakulásáról is elmondta véleményét - azt mondhatom, sok esetben sajnos nem hallgattak rá. Mindenesetre ezek a müsorok is kiváló vitaalapnak számíthatnak, továbbá jó példáját nyújtják annak, mi is foglalkoztatta az embereket abban az időben. A kilencvenes évek című sorozat azon darabjai, melyekben Hankiss volt a vendég, mind továbbgondolásra ösztönöznek. Ugyanis markáns véleménye volt az 1988/89-es esztendő versenyfutásáról a politikai hatalomért, mint ahogy az új politikai elit kialakulásáról is, továbbá arról, mi mindent kell megoldania a társadalomnak az elkövetkezendő években. Ezek a nem hosszú beszélgetések rendelkezésre állnak, tehát puszta meghallgatásuk vitára ingerli az embereket, de föképp annak a megvizsgálása lenne szükséges, mit is valósítottunk meg azokból az ajánlásokból, amiket a tudós elmék javasoltak a rendszerváltás előkészítésének éveiben. Az is érdekes vitatéma lehet, képes-e bármely tudós, legyen akármekkora zseni is, beleavatkozni az úgynevezett spontán politikai-társadalmi folyamatokba, vagy a történelem valami isteni (vagy ördögi) terv szerint halad a maga útján. Főképp fiatalok számára lehetne érdekes egy ilyen vitasorozat, hogy aztán ha húsz-harminc esztendő múlva ugyanúgy elöveszik a felvételeket, mint ahogy mi most ajánljuk elővenni Hankiss müsorait, mit szólnak régi önmagukhoz. Szóval mindenképpen önvizsgálatra ösztönöz és bölcsességre nevel egy-egy ilyen visszatekintés.

Ugyanezt - tehát az újrahallgatást és „hasznosítást” - mondhatom el az 1996ban indult Fórum sorozatról, melyben olyan dolgokról beszélgetnek, melyekről nem szoktunk. Sokak lelki épülését szolgálná, ha „tudományos” szinten is végigvinnénk azt a gondolatot, hogy vajon otthon vagyunk-e a világban? Valamint, hogy mit tettünk történelmünk során azért, hogy valamelyest otthon érezzük magunkat? Szinte játékos formában lehet így tanítani, még egy felsőbb fokú tanulmányokat végző intézetben is. Ebben a sorozatban szó esik bünről, gonoszról s arról, vajon hogy került be e két fogalom az életünkbe? De beszélgetnek arról is, mi a szabadság, és mi a játék szerepe az életünkben. Vagy az alkoholé, a tudatmódosító szereké a művészetben. Bizony, ilyenekről sem szoktunk - merünk vitatkozni. Hankiss mert. Azóta sem senki. Nyilván volna, aki merne, csak nem kap lehetőséget. S továbbgondolásra ajánlanám az új elitekről szóló műsor eszmefuttatásait is, kivált, ha elemeznénk, 1990 óta hogyan változott az elit képe. Egyáltalán, mi alakítja az elit csapatát, mi a szerepe, hogyan lehet belekerülni és kikerülni onnan?

S még egy-két ötlet. A hetvenes évek elején, amikor Hankiss még az Irodalomtörténeti Intézetben dolgozott, végeztek egy olyan kutatást, melyröl a Szavak mögött gondolat, vagy ...? címủ mủsorban számol be. Ebben azt mérték fel, az 
emberek milyen értékek alapján és hogyan döntenek. Állítólag úttörő kutatás volt ez, az emberek értékuniverzumával ugyanis addig nemigen foglalkoztak. Nincs ismeretem arról, hogy manapság vannak-e ilyen felmérések. Mindenesetre igencsak érdekes volna ma is megnézni ezt, mert csaknem ötven év nagy idő, s a szakembereket, meg a politikát valószínű érdekelné a felmérés mai eredménye.

Ugyanez vonatkozik arra a kutatásra is, amelyben az irodalmi hősök rangsorolására kérték a kutatásban részt vevő személyeket. Ebben a magyar olvasók értéktudatáról lehetett sokat megtudni, meg arról is, hogy az értékes, klasszikus irodalmat miképpen ismerik. Ma már talán a legtöbb ember nem is halott az akkor emlegetett regényekről, drámákról s azok hőseiről. Kiderülne, mit olvasnak ma az emberek. Egyetemi hallgatók még iskolákat is összehasonlíthatnának, ily módon segítve a mai oktatási gondok közötti eligazodást. Az Esti beszélgetés a bizonytalanság kora címú müsor is azt kínálja, s milyen érdekes lenne, hogy nézzük meg, a tudós elmék mit jósoltak a mai időkre tíz-húsz-harminc évvel ezelött. Bekövetkeztek-e a jóslatok? Ez akár egy konferencia témája is lehetne. Avagy vitatkozhatnánk arról, amit szintén ez utóbb említett müsor kínál: hogyan lehet értelmet adni az életnek, mert sokan értelmetlennek gondolják azt. Érdemes lenne továbbgondolni a Tér-idő 2012-es adását, melyben arról beszélgetnek jövőkutatók, milyen lesz a világ 2025-ben? A müsor elhangzása óta csak hat év telt el, talán ez volt Hankiss Elemér utolsó rádiós szereplése, de ez alatt az idő alatt is hihetetlen sokat változott a világ, bár már akkor elmondták a résztvevők, hogy olyan időszakban vagyunk, amikor nem lehet előre látni. Egyetemi kurzusok témája lehetne bátran belevágni a jövőkutatásba, de legalább ilyen hasznos lenne, ha közönség előtt vitatkoznának jövőkutatók arról, merre haladunk, hiszen közben le lehetne mérni, mit gondolnak az emberek minderről. Hankissnak ugyebár könyve van az életstratégiákról, ebben számos kérdést felvet, melyekről külön-külön érdemes lenne szemináriumokat szervezni. A Fórum címü müsorsorozat is alkalmas arra, hogy valamely egyetemi képzés újratárgyalja az abban felvetett kérdéseket.

Millió ötletet lehet még meríteni Hankiss rádiós munkásságából. A Felsőbbfokú Tanulmányok Intézetének alkalmi munkatársaként írom ezeket a sorokat, s tudom, hogy fel is fogják használni az ajánlásokat Hankiss Elemér életmüvének minél alaposabb megismertetésére. Ám mindenképpen jó lenne, ha az ő gondolatait az egyetemek falain kívül is megismerhetnék. Mindaz, amit ő hátrahagyott, engem - ez már személyes ügy - maradéktalanul lenyügözött. Szinte biztos, hogy Hankiss ezt sosem mondta ki, munkásságából mégis egyértelmüen kitünik a ,józsefattilai” fogadalom maradéktalan megvalósítása: „Én egész népemet fogom, nem középiskolás fokon tanítani." 